\title{
Nematode Damage to Plantain (Musa spp. AAB-Group) at Flowering as Affected by Paring and Organic Mulch in South- western Nigeria
}

\author{
M. Omolara Olaniyi ${ }^{1}$ \\ Biology Programme, School of Science and Technology, National Open University of Nigeria, P.M.B. 80067 \\ Victoria Island, Lagos.
}

\begin{abstract}
The experiment investigated the effects of paring, oil palm bunch refuse and sawdust mulches on the flowering of mother plant, development of suckers, and the establishment, population and damage dynamics of plant parasitic nematodes on plantain cultivar Agbagba in Southwestern Nigeria. A multifactorial experiment was laid out in a randomized complete block design. Above-ground plant growth parameters were measured at flowering of mother plants. Twenty-two months after planting (MAP), mats were sampled to assess nematode population densities, root and rhizome damages. Results of this study showed that paring and mulching gave complementarily effect on early flowering of plants, improved root production and the extent of benefit was dependent on the type of mulch material used. Pared plants produced fewer suckers at flowering than the nonpared plants, had healthier roots and lower root infections associated with plant parasitic nematode damage. Oil palm bunch refuse was superior to the sawdust mulch in enhancing plant growth, root health and suppressing nematode population densities. In an integrated pest management context therefore, paring coupled with mulching is recommended to boost plantain production.
\end{abstract}

Keywords: Agbagba, plant growth, paring, plant parasitic nematodes, plantain, root health

\section{Introduction}

Plant parasitic nematodes associated with plantain damage in Nigeria include Helicotylenchus dihystera, multicinctus, Meloidogyne spp, Pratylenchus coffeae and Radopholus similis. Of these, P. coffeae was classified as the most serious closely followed by $R$. similis relative to association with root and plant damage indices and the nematodes were reported to cause 30\% loss in Nigeria (Speijer et al., 2001). The authors also established that $R$. similis was prevalent in Southeastern Nigeria while in southwestern Nigeria it was $P$. coffeae that predominates. Subsequently, Rotimi et al. (2004a \& b) investigated the extent of yield loss to plantain as a result of nematode damage in Southeastern Nigeria and recorded between $46 \%$ and $54 \%$ yield reduction from $R$. similis and a complex of other associated plant parasitic nematodes but without P. coffeae. The authors noted that the extent of loss was dependent on the genotype planted, soil fertility status and management.

Similarly in line with the observations of Speijer et al. (2001) with the Nigeria average, Rotimi et al., (2004b) further noted that $R$. similis related loss could be about 33\% absolute yield loss due to toppling of plant bearing immature bunches. It is not known however, the extent of yield loss possible with $P$. coffeae in association with other less damaging species in Nigeria. Since $P$. coffeae is ranked the most damaging species in Nigeria and predominant in the Southwest, it is necessary to site trials in that location in order to be able to access the damage potential of the species.

Effective management of these nematodes would improve production and increase longevity of plantain plantation. Suitable agronomic practices which reduce the loss to pathogens and address soil fertility depletion are required as poor soil fertility aggravates pests and diseases symptoms thereby increasing the cost of management. Mulching is also reputed to mitigate the impact of plant parasitic nematodes on plantain (Rotimi et al., 2004a \& b) especially when applied to low fertility systems (McIntyre et al., 2000).

The relevance of organic mulch to soil management and it influence on the plant growth cannot be overemphasized. Organic mulch, like crop residues, has been used in gardens, plantation crops and arable crops for centuries to add organic matter to the soil and do smother weeds (Akobundu, 1987). Mulching is reported to enhance plantain growth rate, support better sucker production and produce more leaves with larger areas (Rotimi et al., 2004b). The investigators noted that organic mulch maintained more favorable physical and chemical soil condition than unmulched treatments. Other benefits of mulching are that mulch protects soil from

\footnotetext{
${ }^{1}$ The study was undertaken when author was with the Department of Crop, Soil and Pest Management, School of Agriculture and Agricultural Technology, Federal University of Technology, P.M.B. 704 Akure, Ondo State, Nigeria.
} 
direct rain drops and in doing so effects soil conservation. Mulching has been reported by Lawson and Lal (1997) to reduce the soil temperatures and temperature fluctuation (Rotimi, et al., 2004b), which is most beneficial to root growth and development and other soil organism that play important roles in organic matter degradation. Mulching is a way of increasing plant food in the soil (Hahon et al., 1996). When microorganisms and other physical processes mineralize the mulch, the nutrients in them become available to plants.

Mulching also creates a stabilized organic function accumulation in the soil with continued application of mulch over time. Mulches have been obtained from several sources and used for various reasons, including physical improvement of soil. These include plant and animal materials or residues of plants like legumes (for example, Stylosanthes spp, Centrosema spp, Mucuna pruriens, Crotalaria junces, Vigna unguiculata, Glycine max, Phaseolis lunatus); grasses (for example, Panicum maximum, Pennisetum purpureum and Imperata cylindrical); others include Tithonia diversifolia, groundnut shell, sawdust, oil palm bunch refuse and wood chips (Ruhigwa et al., 1995; Rotimi, 2004a; Olaniyi, 2006).

The use of organic mulches has long been recognized and accepted as a form of biological control (Cook and Baker, 1983; Cook et al., 1978). In addition, many examples are available showing that the addition or the management of organic mulches and organic soil amendments has resulted in the stimulation of activities of specific biological agents that directly affected the larger pathogens. For example, the addition of chitin amendments to soil increased several fungal species with chitinolytic ability which was also colonizers of nematode eggs (Cook and Baker, 1983). Organic mulches are also known to influence the survival, production and dissemination of primary and secondary innocula of aerial and soil borne plant pathogens.

Breeding of plant for resistance to plant parasitic nematodes takes a long time to develop and the use of nematicides though effective in the control of Musa nematodes (Gowen and Queneherve, 1990), is expensive for resource poor farmers. The chemical products are also often unavailable in rural areas of Africa. The use of clean planting materials would be the practical solution to reducing nematode problem for Africa's resource poor farmers since it has been established that the use of infected planting materials is a major source of nematodes infection in Nigeria (Speijer et al., 2001, Olaniyi, 2006) and that plantain root health is greatly improved with the use of clean planting materials (Rotimi et al., 2005).

Although use of tissue culture is an important source of clean materials, this could be quite expensive for the resource poor peasant farmers who cultivate the crop and it involves a lot of technical skills too. An alternative would be to engage in physical cleaning of conventional sucker planting materials. Suckers with adhering soils are often used by the peasant farmers to establish new fields and they rarely engage in any form of cleaning (Swennen 1990; Speijer et al., 2001). Physical disinfestations of the sucker may be done by paring, which is the careful peeling of epidermal layer of the corn and the adjoining roots and removal of adhering soil that usually serve as habitat of migratory nematodes (Olaniyi, 2006). Thus, cleaning in this way will prevent transfer of the pest from one field to the other (Olaniyi and Opadare, 2006). Therefore, this study investigated the comparative effect of oilpalm bunch refuse and sawdust mulches on plantain root health and flowering responses to physical disinfestation through paring.

\section{II.1 Experimental Site and Setup}

\section{Materials and Method}

The experiment was carried out at the Crop Section of the Teaching and Research Farm (Crop Section) of the Federal University of Technology, Akure. Akure lies between latitude $5^{\circ} \mathrm{N}$ of the equator and is within the tropical rain forest belt, with an average annual rainfall of about $1613 \mathrm{~mm}$ per annum and an annual mean temperature of about $27^{\circ} \mathrm{C}$.

The experiment was multifactorial with six treatment combinations arranged in a randomized complete block design (RCBD) in three replicates. Factors investigated were two (2) levels of paring (i.e. pared and not pared) and three (3) levels of mulching (oil palm bunch refuse, sawdust and no mulch). This gave a total of six treatment combinations. Each treatment was assigned to a plot making a total of six plots (representing the treatments) per block. Plants were arranged within plots at a $2 \mathrm{~m} \times 3 \mathrm{~m}$ spacing between and within rows respectively. Each plot was separated from the next by a $3 \mathrm{~m}$ alley while blocks were separated by $4 \mathrm{~m}$ alleys. Each plot had six plants.

Before the observations reported in this study began, mulch had been applied at the base of each plant six months after field establishment to plants that received the mulch treatments (Olaniyi, 2006). Five months after, mulches were renewed at the rate of $4.1 \mathrm{~cm}^{3}$ per plant when it was observed that the previous ones had decayed. This represented $9.7 \mathrm{~kg}$ per plant for the oil palm bunch refuse and $3.75 \mathrm{~kg}$ per plant for the sawdust. Chemical analysis of the mulch materials showed that oil palm bunch refuse had $7.71 \% \mathrm{~N}, 928.3 \mathrm{ppm} \mathrm{P}$ and $0.43 \mathrm{Cmol} / \mathrm{kg}$; while sawdust had 2.63\% N, $361.9 \mathrm{ppm} \mathrm{P}$ and $0.13 \mathrm{Cmol} / \mathrm{kg} \mathrm{K}$ (Olaniyi, 2006).

The soil at the experimental site was sandy but had high clay content, prone to compaction, and low in fertility and organic matter content (Ewulo, 2004). Pre-plant soil examination revealed that Helicotylenchus multicinctus, Helicotylenchus dihystera, Meloidogyne spp, Radopholus similis, and Pratylenchus coffeae are the 
predominant plant parasitic nematodes in the field. All these were also present in the root sampled from $20 \mathrm{x} 20$ x $20 \mathrm{~cm}^{3}$ soil excavation from the base of each mat (Olaniyi, 2006) at six months after planting (MAP) when the investigation reported here began.

History of the field shows that weeds were controlled in the field by manually slashing at 4 weeks interval until January 2006 and between March and July 2006. When manual weeding could not be sustained due to high rate of weed growth and cost, chemical control was then employed with glyphosate at the rate of $3.5 \mathrm{~kg}$ a. i per hectare. Herbicide was applied three (3) times between August 2006 and May 2007. Application of NPK 12-12-17-MgO fertilizer was done a couple of times (8 and $14 \mathrm{MAP}$ ) at the rate of $60 \mathrm{~g}$ and $30 \mathrm{~g}$ respectively, in a band at the base of the plant/mat. No fungicide was applied throughout the duration of the experiment (Olaniyi, 2007).

\section{II.2 Plant Growth Parameters}

At the onset of flowering of each mother plant, above ground plant growth parameters were measured for mother plant. A plant was considered to have flowered on the day the tip of the inflorescence was first observed. Above ground parameters measured at flowering included: height of mother plant from soil level to the point of intersection of the last furled and the unfurled leaves (HT), girth of pseudostem at soil level (GTH), number of green (functional) leaves (GLV), and dead (non-functional) leaves (DLV). A leaf is said to be green or functional if at least $75 \%$ of the surface area was green. The number of suckers (SUC) was also counted. The length of the youngest leaf opened (LYL) was measured as the distance from the base to the apex of the youngest leaf opened. The width of the youngest leaf opened (WYL) was measured at the widest portion of the leaf lamina. The leaf area of the youngest leaf opened (YLA) was computed as LYL x WYL x 0.83 (Obiefuna and Ndubizu, 1983).

\section{II.3 Estimation of root damage and nematode population densities at flowering of mother plants}

Root damage at flowering was assessed according to the methodology described by Speijer and De Waele (1997). A $20 \times 20 \times 20 \mathrm{~cm}^{3}$ excavations was dug at the base of each mat and roots from each excavation were collected. Percentage of the roots collected that were dead was recorded. Five functional root pieces were randomly selected from the sample and each reduced to $10 \mathrm{~cm}$ length. The roots were sliced longitudinally and scored for percentage root necrosis (RNI). Feeder roots health (FRH) was assessed on a four-point scale (1-4); 1 being completely healthy and 4 being completely dead.

After root damage assessment, for each sample, the root segments were chopped into approximately $2 \mathrm{~mm}$ pieces and homogenized. A Baermann dish modification of the Baermann funnel method (Hopper, 1990) was used for nematode extraction. Five gramme sub-samples of the homogenized root pieces were first macerated in a kitchen blender. The macerated root tissues were gently poured into plastic sieves covered with tissue paper. Prior to pouring the macerated root tissue suspension in it, the sieve had been placed in a plastic dish. Thereafter, small amount of water was poured into the plastic dish. The base of the sieve made contact with the thin film on the water surface so that active nematodes could move from the macerated tissue suspension, through the sieve into the water in the dish beneath.

The setup was left to rest for 18 hours during which active nematodes migrated from the sieve into the dish. The method is referred to as the. The filtrate (nematode suspension) was collected, left to stand for 8 hours before reducing to $30 \mathrm{ml}$ with a siphon. Three $2 \mathrm{ml}$ aliquots of each suspension were separately taken for nematode identification and population density counts. The plant parasitic nematodes were identified to species level under a light microscope and their population densities extrapolated accordingly. Except for Meloidogyne spp., population density of each species was calculated as the sum of all developmental stages (Juveniles, females and males). For Meloidogyne spp, only the vermiform juveniles and the males could be recovered by the extraction method used, and their sum thus constituted the population.

\section{II.4 Data analysis}

The nematode population densities were $\log (\mathrm{x}+1)$ transformed (Gomez and Gomez, 1984), damage parameters in percentages and scores were arcsine $(\mathrm{x} / 100)$ and $(\mathrm{x}+0.5)$ transformed, respectively, while other counted data were square root transformed prior to using the Generals Linear model in Statistical Package for Social Science (SPSS). Where statistical differences were observed, means were separated using the Duncan Multiple Range Test (DMRT).

\section{Results \\ III.1 Effect of paring and mulch types on vegetative growth parameters of mother plants at flowering \\ The results revealed that mulched plants had better growth even at flowering than the non-mulched ones. Pared plants were shorter than non-pared plants while mulched plants were taller than non-mulched plants whether pared or not. The opposite was the case with the pseudostem girth as pared plants had thicker}


pseudostems than the unpared (Table 1). Plants mulched with oil palm bunch refuse had the highest number of functional leaves whether pared or not although these were not statistically different from number produced on plants mulched with sawdust. For instance, pared plants that received sawdust mulch had the highest number of leaves (13.79) at flowering compared with the least (12.75) produced on the non-pared plants that received no mulch.

\section{III.2 Effect of paring and mulch types on root health of mother plant at flowering}

At flowering, mulching had a strong influence on average weight of roots (ARtWt) excavated from a $20 \times 20 \times 20 \mathrm{~cm}^{3}$ hole at the base of the mat. The PMO produced the heaviest roots per volume of excavated soil while the NPMN produced the least (Table 2). An overview of treatments effect did not show any significant difference $(\mathrm{P} \leq 0.05)$ on percentage of non-functional /dead roots $(\mathrm{DE})$ although the NPMN had the highest mean in this regard and the PMO had the least. This was also the same for the functional roots (OK). Generally, lower values were recorded for dead roots and root necrosis index for non-pared plants. However, root necrosis index (RNI) assessments showed that the PMO was the least necrotic followed by the NPMO. It was also observed in this study that the feeder roots produced by the not mulched plants in this study were not as many as those produced by the mulched plants.

\section{III.3 Effects of paring and mulch types on plant parasitic nematode population densities 22 months after planting}

Five plant parasitic nematode species namely Helicotylenchus dihystera, H. multicinctus, Meloidogyne spp, Pratylenchus coffeae and Radopholus similis were recovered from roots of flowered plantain cvr. Agbagba in this study. Population densities and compositions of these nematodes differed under the different treatments (Fig 1). Radopholus similis had its highest density under the mulched treatments. Apart from R. similis, the plant parasitic nematode population densities constituted a lower percentage in the mulched treatments than the not mulched ones.

Table 1: Effects of paring and mulch types on selected vegetative growth parameters at flowering of mother

\begin{tabular}{|c|c|c|c|c|c|c|c|c|c|}
\hline Treatments & HT(cm) & GTH(cm) & GLV & DLV & TNL & LYL(cm) & WYL(cm) & LA(cm2) & \#SUC \\
\hline NPMN & $227.75 a$ & $52.25 \mathrm{a}$ & $12.75 b$ & $12.25 \mathrm{ab}$ & $25.00 \mathrm{a}$ & $93.00 \mathrm{a}$ & $48.75 \mathrm{a}$ & $3663.60 \mathrm{a}$ & $7.75 b c$ \\
\hline NPMO & $266.79 a$ & $57.71 \mathrm{a}$ & $13.70 \mathrm{a}$ & $13.08 \mathrm{ab}$ & $26.78 \mathrm{a}$ & $98.65 \mathrm{a}$ & $53.46 \mathrm{a}$ & $4328.95 \mathrm{a}$ & $11.42 \mathrm{a}$ \\
\hline NPMS & $262.77 \mathrm{a}$ & $57.50 \mathrm{a}$ & $13.15 \mathrm{ab}$ & $12.00 \mathrm{~b}$ & $25.15 \mathrm{a}$ & $102.11 \mathrm{a}$ & $47.83 \mathrm{a}$ & $3918.04 a$ & $11.11 \mathrm{ab}$ \\
\hline PMN & $223.75 a$ & $55.08 \mathrm{a}$ & $12.90 \mathrm{~b}$ & $12.21 \mathrm{~b}$ & $25.11 \mathrm{a}$ & $79.63 \mathrm{a}$ & $43.04 \mathrm{a}$ & $2783.97 \mathrm{a}$ & $7.08 \mathrm{c}$ \\
\hline PMO & $252.81 \mathrm{a}$ & $62.23 \mathrm{a}$ & $13.79 \mathrm{a}$ & $16.15 \mathrm{a}$ & $29.94 \mathrm{a}$ & $95.56 \mathrm{a}$ & $45.00 \mathrm{a}$ & $3449.98 \mathrm{a}$ & $10.54 \mathrm{abc}$ \\
\hline PMS & $251.39 \mathrm{a}$ & $57.78 \mathrm{a}$ & $13.17 \mathrm{ab}$ & $13.50 \mathrm{ab}$ & $26.61 \mathrm{a}$ & $97.50 \mathrm{a}$ & $49.33 a$ & $3862.40 \mathrm{a}$ & $9.39 \mathrm{abc}$ \\
\hline $\mathbf{N}$ & 52 & 52 & 52 & 52 & 52 & 52 & 52 & 52 & 52 \\
\hline
\end{tabular}

HT: height of mother plant from soil level to the point of intersection of the last furled and the unfurled leaves in $\mathrm{cm}$;

GTH: girth of pseudostem at soil level; GLV: green (functional) leaves;

DLV: dead (non-functional) leaves;

TNL: total number of leaves; LYL: length of youngest leaf opened;

WYL: width of youngest leaf opened; LA: leaf area of the youngest leaf opened at flowering;

SUC: number of suckers at flowering; N: total number of plants used.

Table 2: Effects of paring and mulch types on root health of mother plant at flowering

\begin{tabular}{lllllll}
\hline Treatments & ARtWt(cm) & A\#R & DE (\%) & OK (\%) & RNI (\%) & FRH \\
\hline NPMN & $9.25 \mathrm{~d}$ & $8.74 \mathrm{~d}$ & $21.25 \mathrm{a}$ & $78.89 \mathrm{a}$ & $14.83 \mathrm{~b}$ & $2.00 \mathrm{a}$ \\
NPMO & $20.35 \mathrm{ab}$ & $17.45 \mathrm{~b}$ & $17.35 \mathrm{a}$ & $82.67 \mathrm{a}$ & $13.46 \mathrm{ab}$ & $2.12 \mathrm{ab}$ \\
NPMS & $21.33 \mathrm{ab}$ & $17.42 \mathrm{~b}$ & $21.91 \mathrm{a}$ & $78.10 \mathrm{a}$ & $14.76 \mathrm{ab}$ & $2.25 \mathrm{ab}$ \\
& & & & & & \\
PMN & $14.53 \mathrm{c}$ & $14.78 \mathrm{c}$ & $20.07 \mathrm{a}$ & $79.95 \mathrm{a}$ & $14.52 \mathrm{ab}$ & $1.87 \mathrm{a}$ \\
PMO & $27.38 \mathrm{a}$ & $21.35 \mathrm{a}$ & $16.64 \mathrm{a}$ & $83.38 \mathrm{a}$ & $11.96 \mathrm{a}$ & $2.00 \mathrm{a}$ \\
PMS & $25.10 \mathrm{a}$ & $18.93 \mathrm{~b}$ & $20.98 \mathrm{a}$ & $75.52 \mathrm{a}$ & $13.87 \mathrm{ab}$ & $2.40 \mathrm{~b}$ \\
N & 52 & 52 & 52 & 52 & 52 & 52 \\
\hline
\end{tabular}

ARtWt: average root weight;

A\#R: average number of roots;

DE: dead roots;

OK: functional roots; RNI: root necrosis index; 
FRH: feeder root health

PMO: pared and oil palm bunch refuse mulched;

NPMO: not pared but oil palm bunch refuse mulched; PMS: pared and sawdust mulched;

NPMS: not pared but sawdust mulched;

PMN: pared but not mulched;

NPMN: not pared and not mulched; and MAP: months after planting. (Error bars are displayed on npmn)

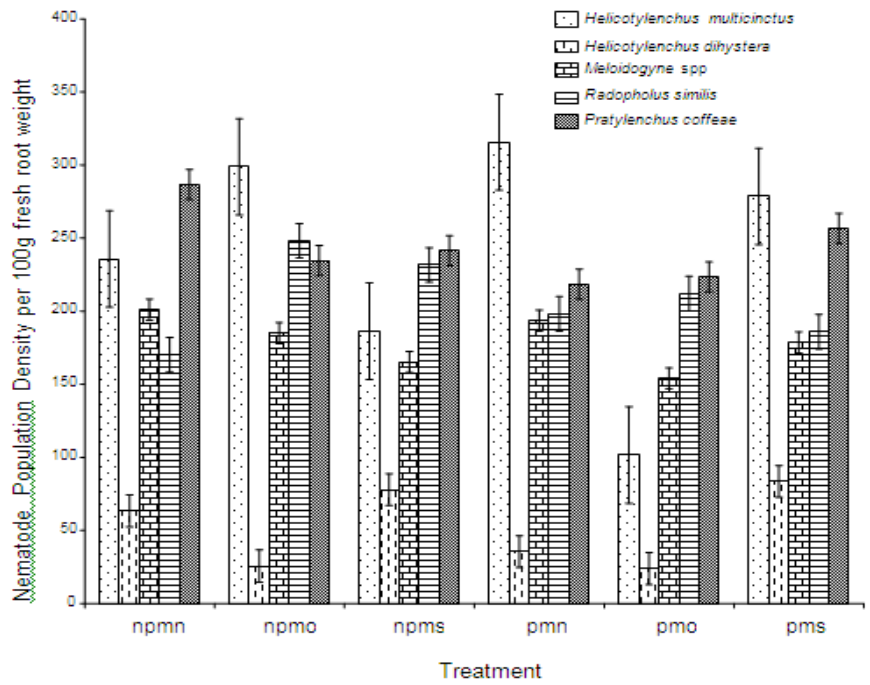

Figure 1: Nematode densities per 100g root extracted from roots of mother plant at flowering.

npmn: not pared and not mulched; npmo: not pared but oil palm bunch refuse mulched; npms: not pared but sawdust mulched; pmn: pared but not mulched; pmo: pared and oil palm bunch refuse mulched; pms: pared and sawdust mulched; Error bars are displayed on the columns.

\section{Discussion}

Plantain under the six treatments reached statistically similar pseudostem heights at flowering although plants that were established with pared suckers and mulched with oil palm bunch refuse flowered earlier than the other five treatments (data not shown). This implied that additional benefit would be derived from paring, it would be dependent on the type of organic input applied in plantain production. Non-pared plants irrespective of mulch type were generally taller and with thinner pseudostems at the time of flowering, than plants that were pared before planting indicating that paring probably resulted in stout and shorter plants. This may be an attractive benefit of paring as tall plants tend to lodge easily in a wet and windy weather (Blake, 1969). It is also the first time that these types of benefits of paring to plantain growth response would be documented.

The range of $223.75-266.79 \mathrm{~cm}$ in height of flowered plants observed in this study did not fall within the range of 273-434 cm reported by Speijer et al. (2001) for Nigeria while the pseudostem thickness range of $52.25-52.23 \mathrm{~cm}$ recorded in this study was lower than the $59 \mathrm{~cm}$ average reported by the authors. However, the ranges were within what was reported by Rotimi et al. (2004b) for the same plantain cultivar, Agbagba, in Onne, Southeastern Nigeria.

Furthermore, pared plants produced more functional leaves that were shorter with resultant smaller area while the unpared plants had fewer leaves which had wider area than the pared plants. The wider leaf area could have been a compensation for the fewer number of leaves produced. More green leaves with shorter and narrower lamina and eventually smaller area in the pared treatment might be beneficial in reducing the negative impact of wind that gives the leaves shredded appearance and result in reduced photosynthetic area. This relationship would be helpful in developing a cultural strategy that would help plantain withstand the impact of climate change like increased wind damage. This is the first report of wider leaf area being associated with fewer leaves on plantain at flowering.

Compared with a related study in Southeastern Nigeria, mulched plants had produced more suckers during vegetative stage from 250 to about 320 days after planting but nematode inoculation of the mulched plants (representing the unpared condition) resulted in dichotomy in which more suckers were produced by the inoculated mulched plants than the uninoculated (Rotimi et al., 2004a). In the present study, non-pared treatment could be said to represent the nematode inoculated situation and hence the increased suckering under the non-pared situation is similar to Rotimi et al.'s (2004a) report where non-pared plants produced more 
suckers. Paring probably stabilized physiological processes and reduced biotic stress like plant parasitic nematode infection which was reduced in the pared treatment in this study.

The non-pared situation might have provided a conducive environment for biotic stress organisms like plant parasitic nematodes, which are known to be primarily transmitted by infested planting materials. This might have resulted in increased root damage, which might have in turn stimulated increased suckering to compensate for root decline, with resultant larger leaf areas of the fewer leaves on the mother plant. High sucker production at flowering might not be profitable for plantain yield because the high number of sucker might result in high competition for assimilates among the suckers (Rotimi et al., 2004b) and also with the filling fruit, which is the preferential sink for assimilates after flower emergence (Akobundu, 1987; Russell, 1988). However, it is not clear if the suckers still had unexpanded leaves, which would compete with the flowering mother plant as sink of assimilate or they had expanded leaves, which would be able to complement the leaves of the flowering mother plant in production of assimilate for fruit filling. Hence, it is necessary to further study the growth pattern of a few of these following ratoons. It would also be necessary to verify if large number of suckers would be beneficial or detrimental for bunch yield under the treatments in this study by investigating the leaf area expansion rate of a few followers in relation to the yield.

Paring and mulching resulted in early flowering of plants. This may not be unrelated to the higher growth rate of the mulched plants. The early flowering would result in a situation where the plantain fruits matured faster and are harvested earlier thus increasing the cycling rate of the mats (Rotimi et al., 2004b; Coyne et al., 2005).

Root to shoot ratio is an important factor in plant growth. Higher root:shoot ratio could mean that root system of the suckers also contributed to heavier roots in the excavation. The mother plant's root system would then be reinforced by that of the suckers produced and there is evidence that more roots were produced in the pared treatments than in the non-pared. If the extent of the root system is reduced, plant anchorage in the soil is weakened and under the weight of a maturing bunch, such a plant is prone to toppling over in predisposing conditions (Blake, 1969; Robinson, 1996; Rotimi et al., 2004b). Therefore, the pared treatment would support better plant anchorage and the impact of this on fruit filling and toppling over incidence should be verified. Mulch effect was pronounced on root production; heavier roots were produced under mulch than the nonmulched and this could be due to the higher production of feeder roots as established by Olaniyi (2011) under mulch treatment. Visual observations not empirically documented showed that feeder roots were heavily concentrated in the excavations from the mulched treatments; especially under the oilpalm bunch refuse mulch.

Interactive effect of paring and mulching showed that paring further strengthened the beneficial effect of mulch with pared plants that were mulched having more, heavier and healthier roots, irrespective of the mulch material when pared. The extent of beneficial effect with mulch was dependent on the type of mulch material used as the oilpalm bunch refuse supported more roots than the sawdust mulch. These findings concurred with earlier report that mulching generally influence root proliferation (Salau et al.,1992; Sainju and Good, 1993) while paring improve root health of plantain and, it is suspected to stimulate production and development of new roots (Olaniyi and Opadare, 2006).

Nematode populations were expectedly different under the various treatments. One logical explanation for this is that different cultural practices create peculiar niches having varying degrees of characteristics. Therefore, the activities of each nematode species would be dependent on the niche in which it exists. Although, it is widely accepted that the host plant is the major influence in plant parasitic nematode community dynamics (Norton, 1978), the soil environment undoubtedly affects nematode population growth and species survival by physical and physiological impact on the nematode and through positive and negative effects on the host plant.

Moreover, the findings in this study showed that paring resulted in reduced nematode population densities considering the lower nematode densities observed in the pared treatments compared to the non-pared counterparts. This emphasizes the importance of clean planting materials, as already infested materials can serve as sources of inoculum in an initially uninfested field with the population reaching economically damaging levels over time (Speijer et al., 2001; Rotimi et al., 2004a \& b).

Inter-specific competitive relationship among concomitant species was observed for Helicotylenchus multicinctus, Pratylenchus coffeae and Radopholus similis. The root population of $H$. multicinctus seemed to be dependent on population of either $P$. coffeae or $R$. similis, or both, under different treatment conditions. It was observed that where the population density of $P$. coffeae and/or $R$. similis was high, that of $H$. multicinctus was low; and vice-versa. There could have been competitions for feeding sites and it is highly probable that the feeding sites of $H$. multicinctus were destroyed by the activities of $R$. similis and $P$. coffeae, the deeper feeders (Rotimi et al., 2005). The challenge of managing pests and protecting our agroecozones is a complex and delicate one that needed to be treated as such, most especially in view of the problem of global warming and chemical residue in crops, which is generating the clamour for reduced usage of agrochemicals. 
Hence as demonstrated in this study, the use of biologically-oriented and environmentally-friendly options, such as mulching and paring, are recommended in managing plant parasitic nematodes for sustainable production in an integrated pest management approach.

\section{Acknowledgements}

The establishment of the trial was funded by the Centre for Research and Development (CERAD) of the Federal University of Technology, Akure, Nigeria but further maintenance for the study reported in this paper was made possible through the research grant (number C/3859-1) of the International Foundation for Science (IFS), Sweden. The technical support provided by Gideon Alake and Wole Osuloye with data collection is highly appreciated.

\section{References}

[1]. I.O. Akobundu, Weed science in the tropics (John Willey and Sons Ltd, NY, 1987) $522 \mathrm{pp.}$

[2]. C.D. Blake, Nematode parasites of banana and their control, in J.E Peachey (Ed.), Parasitic Nematodes of Food Crops, Technical Communication No. 40 (Commonwealth Agricultural Bureau, England, 1969) 109-141.

[3]. R.J. Cook, M.G. Brosalis and K.B. Doupani, Influence of crop residues on plant diseases, in Crop Residue Management Systems 8, Am. soc. Agron Spec. Publish, Madison, 1978) 144-163.

[4]. R.J. Cook and K.F. Baker. The nature and practice of biological control of plant pathogens, (American phytopathological Society, St. Paul MN,1983). 539pp.

[5]. D. Coyne, O. Rotimi, P.,Speijer, B. Schuster, T. Dubors, A. Auwerkerken, A. Tenkouano, and D. De Waele,. Effects of nematode infection and mulching on the yield of plantain (Musa spp, AAB group) ratoon crops and plantain longevity in Southeastern Nigeria. Nematology 7, 2005, 531-541.

[6]. B.S. Ewulo, Effect of reduced tillage and mulch on the properties of an alfisol and maize performance in southwestern Nigeria, Ph.D thesis submitted to the department of C,op, Soil and pest Management, Shool of Agriculture and Agricultural Technology, Federal University of Technology, Akure, 2004.

[7]. K.A. Gomez and A.A. Gomez, Statistical Procedures for Agricultural Research, (John Wiley and Sons, Inc., New York, USA, 1984).

[8]. S.R. Gowen and P. Queneherve, Nematode parasites of bananas, plantains and abaca, in M. Luc, R.A. Sikora and J. Bridge (Eds), Plant Parasitic Nematodes in Sub-tropical and tropical agriculture, (First edition. CAB International, Wallingford, UK, 1990) 431460 .

[9]. D.J. Hooper, Extraction and processing of plant and soil nematodes. In: M., Luc, R.A. Sikora and J. Bridge (Eds.). Plant parasitic nematodes in subtropical and tropical agriculture, (CAB International, Wallingford, UK, 1990) 45-68.

[10]. T. Lawson, and R. Lal, Response of maize (Zea mays I) to surface and buried straw in tropical adfosol. Soil Tillage and Crop Production Proc. series No. 2, International Institute of Tropical Agriculture, Ibadan, 1997, 26-30.

[11]. B.D. McIntyre, P.R. Speijer, S.J. Ralia, F. Kizito, Effects of mulching on biomas, nutrients and soil water in banana incubated with nematodes. Agron J. 92, 2000, 1081-1085.

[12]. D.C. Norton. Ecology of Plant-Parasitic Nematodes, (John Wiley and Sons, New York, 1978) 268 pp.

[13]. J.C. Obiefuna and T.O.C. Ndubizu,. Estimating leaf area of plantain. Scientia Horticulturae 11, 1983, 31-36.

[14]. M.O. Olaniyi, Effects of paring and types of organic mulch on nematode infection, growth, yield and yield quality of plantain, Progress Report, Centre for Research and Development (CERAD), Federal University of Technology, Akure (FUTA), 2006.

[15]. M.O. Olaniyi, Effects of paring and types of organic mulch on nematode infection, growth yield and yield quality of plantain. End of Project Report, Centre for Research and Development (CERAD), Federal University of Technology, Akure (FUTA), 2007.

[16]. M.O. Olaniyi, Plant parasitic nematode constraint to plantain production in Nigeria (LAP Lambert Publishing, Germany, ISBN 9783-8454-2312-8, 2011).

[17]. M.O. Olaniyi and S. Opadare, Effect of paring on the establishment and root damage of French plantain suckers. ANAIS Proc. memorias XVII Reuniao International ACORBAT, Join ville-Santz Catarina-Brasil, 2006, 345

[18]. J.C. Robinson, Bananas and plantains, Crop production in horticulture. 5. (CAB International. Wallingford, UK, 1996).

[19]. M. O. Rotimi, P. Speijer, D. De Waele and R. Swennen, Effect of mulching on the response of plantain cv. Agbagba (Musa spp., AAB-group) to plant parasitic nematodes in southeastern Nigeria I: Vegetative growth. Nigerian Journal of Forestry 34, 2004a, 6170 .

[20]. M. O. Rotimi, P. Speijer, D. De Waele and R. Swennen, Effect of mulching on the response of plantain cv. Agbagba (Musa spp., AAB-group) to plant parasitic nematodes in southeastern Nigeria II: Reproductive growth and yield. Nigerian Journal of Forestry 34, 2004b, 102-111.

[21]. M. O. Rotimi, P. Speijer, D. De Waele and R. Swennen. Effect of inoculum density of plant parasitic nematodes on the root reaction of a False Horn and a French plantain. Niger Delta Biologia 5, 2005, 32-47.

[22]. B.A. Ruhigwa, M.P. Gichuru, R. Swennen and N.M Tariah, Plantain production is an alley cropping system on an ultisol in Southeastern Nigeria, in B.T, Kany, A.D. Osiname, and A. Larbi (Eds.), Alley Farming Research and Development. Proceedings of the International Conference on Alley Farming, International Institute of Tropical Agriculture, Ibadan, Nigeria, 1995, $268-277$.

[23]. R.S. Russell, Russell's soil condition and plant growth, $11^{\text {th }}$ edition, in A. Wild (Ed.), (Longman Scientific and Technical, 1988) $113-167$.

[24]. U.M. Sainju and R.E. Good, Vertical root distribution in relation to soil properties in New Jersey pineland forests, Plant and Soil $150,1993,87-97$.

[25]. O.A. Salau, O.A. Opara-Nadi and R. Swennen, Effects of mulching on soil properties, growth and yield of plantain on a tropical ultisol in Southeastern Nigeria. Soil Tillage Research 23, 1992 73-93.

[26]. P.R. Speijer and D. De Waele, Screening of Musa germplasm for resistance and tolerance of nematode. INIBAP technical guidelines (1PGRI Rome, Italy, INIBAP, Montpeller, France, IITA, Ibadan, Nigeria, 1997).

[27]. P.R. Speijer, M.O. Rotimi and D. De Waele, Plant parasitic nematodes associated with plantain (Musa spp., AAB group) in Southeastern Nigeria and their relative importance compared to other biotic constraints Nematology 3, 2001, 423-436.

[28]. R. Swennen, Plantain cultivation under West African conditions, a reference manual, (International Institute of Tropical Agriculture, Ibadan, Nigeria. 1990). 